\title{
Chemical interactions among caseins during rennet coagulation of milk
}

\author{
J. C. Amaro-Hernández, ${ }^{1}$ G. I. Olivas, ${ }^{1} \odot$ C. H. Acosta-Muñiz, ${ }^{1}$ N. Gutiérrez-Méndez, ${ }^{2}$ ๑) C. Rios-Velasco, ${ }^{1}$ \\ and D. R. Sepulveda ${ }^{1 *}$ (1) \\ ${ }^{1}$ Centro de Investigación en Alimentacion y Desarrollo A.C., Unidad Cuauhtémoc, Av. Rio Conchos S/N, Parque Industrial, Ciudad Cuauhtémoc, \\ Chihuahua, México, C.P. 31570 \\ ${ }^{2}$ Facultad de Ciencias Químicas, Universidad Autónoma de Chihuahua, Circuito Universitario 8, Campus UACH II, Chihuahua, Chihuahua, \\ México, C.P. 31125
}

\begin{abstract}
Rennet milk curds were prepared under 4 different temperature and acidity conditions. The development of different types of inter-protein chemical bonds (disulfide, hydrophobic, electrostatic, hydrogen, and calcium bridges) was monitored for 60 min after curd cutting. Hydrophobic inter-protein interactions originally present in casein micelles in milk were substituted by electrostatic, hydrogen, and calcium bonds throughout the curd curing period. Disulfide bonds were not disturbed by the experimental conditions employed in the study, remaining at a constant level in all studied treatments. Acidification of curds increased the availability of soluble ionic calcium, increasing the relative proportion of calcium bridges at the expense of electrostatic-hydrogen bonds. Although $\mathrm{pH}$ defined the nature of the interactions established among proteins in curd, temperature modified the rate at which such bonds were formed.
\end{abstract}

Key words: milk curd, inter-casein chemical bonds, curd caseins interactions

\section{INTRODUCTION}

Bovine milk gels under the action of rennet, forming a complex protein-based tridimensional arrangement (Sinaga et al., 2017; Lamichhane et al., 2018; Mehta, 2018). Paracasein micelles in curd interact mainly by exposing their hydrophobic cores and through electrostatic and calcium-mediated ionic bonds (Panteli et al., 2015; Ono et al., 2017). After the onset of coagulation, some additional rearrangements of the structure occur (Lucey, 2014). External factors such as $\mathrm{pH}$ and temperature play an important role in determining the establishment of the various types of chemical bonds among caseins during this period (Corredig and Salvatore, 2016; Mehta, 2018). The continuous paracasein matrix

Received July 27, 2021.

Accepted October 6, 2021.

*Corresponding author: dsepulveda@ciad.mx physically entraps fat and whey (Geng et al., 2011), creating a structure of high dimensionality supported by casein strands that get thicker through time (Fagan et al., 2017). Depending on the nature and abundance of the formed chemical bonds, the tridimensional protein structure develops a specific capacity to retain whey or to lose it (Mehta, 2018). The driving force behind whey loss is the formation of strong inter-casein interactions that promote micro-syneresis (Walstra et al., 2005), expelling whey as the protein structure becomes denser (Amaro-Hernández et al., 2020).

Although the general mechanism behind curd setting and curing has been abundantly discussed in the literature, the specifics regarding the role played by different types of inter-casein chemical bonds on the development of the proteinaceous curd structure during gel curing remain mostly unknown. An analytical technique reported by Van Camp et al. (1997) and further developed by Keim and Hinrichs (2004) has been suggested as a feasible method to quantify the relative proportion of hydrophobic, electrostatic, hydrogen, calcium, and disulfide bonds in milk gels and other dairy products (Gonçalves and Cardarelli, 2019), providing a means to advance the knowledge in this field.

Based on this, the objective of the present study was to determine the relative proportion of hydrophobic, electrostatic or hydrogen, calcium, and disulfide bonds in curd during a curing period of 60 min under different conditions of $\mathrm{pH}$ and temperature.

\section{MATERIALS AND METHODS}

The relative proportions of hydrophobic, electrostatic, hydrogen, calcium and disulfide bonds among proteins were measured on curd prepared from lactic acid bacteria-inoculated, and uninoculated milk, tempered at 30 and $40^{\circ} \mathrm{C}$, resulting in 4 different treatments. Curd samples were taken every 15 min starting at cutting time, which was considered as time 0 . Whey content and $\mathrm{pH}$ of each sample were determined as well throughout the curing period. 


\section{Curd Manufacturing and Conditioning}

Four pasteurized bovine whole milk aliquots $(2 \mathrm{~L}$ each) were conditioned at 2 different temperatures ( 2 at $30^{\circ} \mathrm{C}$, and 2 at $40^{\circ} \mathrm{C}$ ). One sample of each temperature was inoculated with $0.8 \mathrm{U}$ of lactic acid bacteria $(\mathbf{L A B}$; RTS 743, Chr. Hansen). A resting period of about half an hour allowed inoculated samples to reach a $\mathrm{pH}$ value of 6.2 after a little lag time, ensuring strong LAB activity. Uninoculated samples remained at the original $\mathrm{pH}$ of milk (about 6.7). Once milk samples were LAB and temperature preconditioned, milk coagulation was performed by addition of $100 \mu \mathrm{L}$ (50 international milk clotting units) of a solution of Chy-Max M 1000 (Chr. Hansen). Each sample was left undisturbed for $30 \mathrm{~min}$ until curd formation was complete. Afterward, the set curd was cut into cubes of about $1 \mathrm{~cm}$ and cured immersed in whey, undisturbed, for a period of $60 \mathrm{~min}$. Curd samples were taken every 15 min $(0,15,30,45$, and $60 \mathrm{~min}$ ) for $\mathrm{pH}$, whey content, and analytical characterization of inter-protein chemical bonds.

\section{Whey Content and pH Determinations}

The moisture content of curds was determined for each sample by the standard method 926.08 (AOAC International, 2006a). Soluble solids content of whey was measured employing standard method 990.20 (AOAC International, 2006b), to determine the whey content of curds based on their moisture and soluble solids content. The $\mathrm{pH}$ was measured potentiometrically (Orion Star A211, Thermo Scientific).

\section{Inter-Protein Chemical Bonds}

The method used to characterize chemical bonds is based on selective solubilization of curd protein in different buffer solutions. The assay was performed according to the methodology described by Gonçalves and Cardarelli (2019) with some modifications. Two grams of curd sample was placed in $85-\mathrm{mL}$ polycarbonate tubes together with $20 \mathrm{~mL}$ of 1 of the 4 buffer solutions, A, B, C, or D (Table 1). Each buffer solution dissolves a given protein fraction depending on its particular bond-destabilizing properties. Curds in buffer were homogenized (Ultra-Turrax T25) at room temperature for $5 \mathrm{~min}$ at 13,500 rpm. Samples were then shaken for $20 \mathrm{~min}$ in an orbital agitation shaker (Incubator Shaker Series I26) and centrifuged at $15,000 \times g$ for $23 \mathrm{~min}$ at $20^{\circ} \mathrm{C}$ (Allegra 64R centrifuge/rotor F0685). Afterward, samples were filtered through $0.2-\mu \mathrm{m}$ paper, and the total nitrogen content of each sample was determined using the Kjeldahl method (AOAC International, 2006c). The nitrogen content of each buffer (by itself)
Table 1. Chemical composition of buffers employed for selective protein solubilization

\begin{tabular}{llcl}
\hline Buffer & Composition $^{1}$ & $\mathrm{pH}$ & $\begin{array}{l}\text { Destabilized } \\
\text { bonds }^{2}\end{array}$ \\
\hline $\mathrm{A}$ & $\begin{array}{l}\text { Tris } 12.12 \mathrm{~g} / \mathrm{L} \\
\text { SDS } 1 \mathrm{~g} / \mathrm{L}\end{array}$ & 7.2 & $\mathrm{~EB}, \mathrm{HB}, \mathrm{Hy}$ \\
$\mathrm{B}$ & $\begin{array}{l}\text { Tris } 12.12 \mathrm{~g} / \mathrm{L} \\
\text { SDS } 1 \mathrm{~g} / \mathrm{L}\end{array}$ & 7.2 & $\mathrm{~EB}, \mathrm{HB}, \mathrm{Hy}, \mathrm{SS}$ \\
$\mathrm{C}$ & $\begin{array}{l}\mathrm{DTT} 5 \mathrm{~g} / \mathrm{L} \\
\mathrm{NaCl} 9 \mathrm{~g} / \mathrm{L}\end{array}$ & 7.2 & $\mathrm{~EB}, \mathrm{HB}$ \\
$\mathrm{N}$ & $\mathrm{NaH}_{2} \mathrm{PO} \mathrm{H}_{2} \mathrm{O} 7.8 \mathrm{~g} / \mathrm{L}$ & & $\mathrm{EB}, \mathrm{HB}, \mathrm{CaB}$ \\
\hline
\end{tabular}

${ }^{1}$ Millipore water for buffer preparation; $\mathrm{HCl} / \mathrm{NaOH}$ for $\mathrm{pH}$ adjustment; DTT $=$ dithiothreitol.

${ }^{2} \mathrm{~EB}=$ electrostatic interactions; $\mathrm{HB}=$ hydrogen bridges; Hy = hydrophobic interactions; $\mathrm{SS}=$ disulfide bridges; $\mathrm{CaB}=$ calcium bridges.

was also determined and subtracted from the nitrogen content found for each sample, to block out the buffer's contribution.

Considering the different protein fractions solubilized by each buffer (Table 1), a set of equations was composed to determine the relative abundance of each type of bond from the assayed nitrogen contents:

$$
\begin{gathered}
P(S S)=\frac{N b o n d, B}{N s}-\frac{N b o n d, A}{N s} ; \\
P(H y)=\frac{N b o n d, A}{N s}-\frac{N b o n d, C}{N s} ; \\
P(E B)+P(H B)+P(u b)=\frac{N b o n d, C}{N s} ; \\
P(C a B)=\frac{N b o n d, D}{N s}-\frac{N b o n d, C}{N s},
\end{gathered}
$$

where Nbond,A, Nbond,B, Nbond,C, and Nbond,D correspond to the nitrogen content measured in buffer solutions $A, B, C$, and $D$, respectively $(\mathrm{g} / \mathrm{g}) ; N s$ is the total nitrogen content of curd $(\mathrm{g} / \mathrm{g})$; and $P$ is the proportion of protein (\%) stabilized by a given specific interaction: electrostatic bonds $(\boldsymbol{E} \boldsymbol{B})$, hydrogen bridges $(\boldsymbol{H B})$, hydrophobic interactions $(\boldsymbol{H} \boldsymbol{y})$, disulfide bridges $(S S)$, calcium bonds $(\boldsymbol{C a B})$, and free protein $(u b)$. Due to their similar nature, electrostatic and hydrogen bonds are quantified as a single group in the present study (Equation [3]).

\section{Statistical Analysis}

The experiment was independently repeated 3 times. For each response variable, ANOVA were conducted, considering a $2 \times 2 \times 5$ factorial experimental design, 
with 2 inoculation levels (inoculated and uninoculated), 2 temperature levels $\left(30\right.$ and $\left.40^{\circ} \mathrm{C}\right)$, and 5 curing time levels $(0,15,30,45$, and $60 \mathrm{~min})$. Statistical analyses were performed using SAS software (SAS System for Windows 9.0; SAS Institute Inc.), considering a significance level of $P \leq 0.05$.

\section{RESULTS AND DISCUSSION}

The 4 studied treatment conditions produced different chemical and physical characteristics on the studied curd during the 60 -min curing period. The $\mathrm{pH}$ of the studied samples developed as expected (Figure 1), showing a temperature-dependent decrease in inoculated samples caused by the metabolic activity of LAB. Uninoculated samples, by contrast, remained at a constant $\mathrm{pH}$ level around 6.7 for the duration of the experiment. Concomitantly, LAB-inoculated samples showed a steeper whey loss trend than uninoculated samples (Figure 2), being more pronounced at higher curing temperature $(0.373 \mathrm{~g}$ of whey/min $)$. Uninoculated samples cured at $40^{\circ} \mathrm{C}$ showed a whey loss trend similar to that of inoculated samples cured at $30^{\circ} \mathrm{C}$ (0.150 $\mathrm{g}$ of whey/min), with uninoculated samples cured at $30^{\circ} \mathrm{C}$ showing the least whey loss among the studied samples (0.076 $\mathrm{g}$ of whey/min). This behavior is consistent with previous reports indicating that curd syneresis increases as temperature and acidity increase (Van Vliet et al., 2004; Janhøj and Qvist, 2010).

Regarding the development of the different types of inter-protein chemical bonds during the curing period, it is relevant to mention that disulfide bridges remained at a constant average level of $1.58 \%$ for all treatments during the 60-min curing period, showing no statisti-

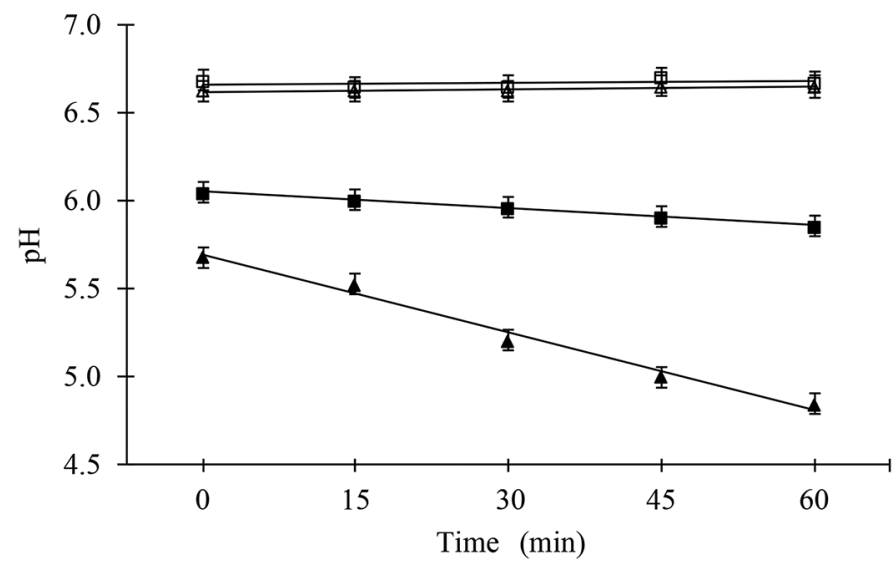

Figure 1. pH development of inoculated and uninoculated curds incubated at different temperatures. Empty markers correspond to uninoculated samples incubated at $30^{\circ} \mathrm{C}(\square)$ and $40^{\circ} \mathrm{C}(\Delta)$. Inoculated samples are represented by filled markers: $30^{\circ} \mathrm{C}(\boldsymbol{\square})$ and $40^{\circ} \mathrm{C}(\boldsymbol{\Delta})$. Error bars represent SE.

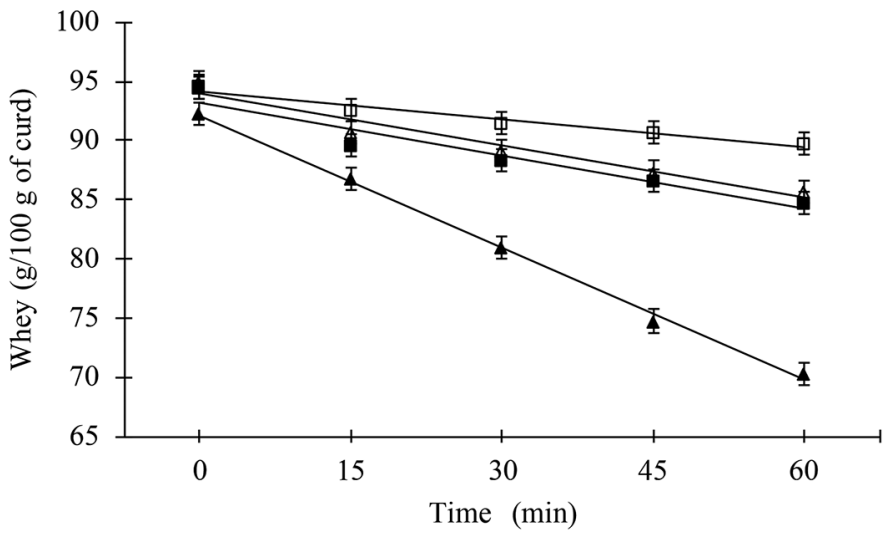

Figure 2. Whey loss in inoculated and uninoculated curds incubated at different temperatures. Empty markers correspond to uninoculated samples incubated at $30^{\circ} \mathrm{C}(\square)$ and $40^{\circ} \mathrm{C}(\Delta)$. Inoculated samples are represented by filled markers: $30^{\circ} \mathrm{C}(\boldsymbol{\square})$ and $40^{\circ} \mathrm{C}(\boldsymbol{\Delta})$. Error bars represent SE.

cally significant difference among them. (The whole model was not statistically significant, showing no effect of temperature, acidification, time, or any of their interactions.) This observation suggests that disulfide bonds are not disturbed by the experimental conditions employed in this study, which is consistent with previous reports by Gonçalves and Cardarelli (2019), who found $2 \%$ disulfide bridges in Mozzarella cheese during the stretching stage. Similarly, Keim et al. (2006) reported $0.5 \%$ disulfide bridges in rennet-induced milk gels. In both cases, the researchers mention that standard processing conditions are not able to change the proportion of disulfide bonds, probably due to their high intrinsic energy (Table 2). The small proportion of disulfide bridges found in curd, in any case, is due to the limited number of thiols in caseins, which is reduced to 2 in $\alpha_{\mathrm{S}_{2}}$-casein and 2 in $\kappa$-casein (Broyard and Gaucheron, 2015; Fox et al., 2017). Reports mentioning higher proportions of disulfide bridges in curd typically include binding of cysteine-rich whey proteins (Table $3)$.

Statistical analyses for the rest of the studied types of bonds (hydrophobic, electrostatic+hydrogen, and calcium bridges) indicated statistically significant effects of temperature and LAB inoculation (acidification) in all of them, establishing the unequivocal dependence of bond formation with acidity and temperature. The effect of temperature in the case of formation of electrostatic+hydrogen bonds appeared to be interdependent on time, as a statistically significant interaction between temperature and time was found. In a similar way, hydrophobic bond formation showed a statistically significant interaction between temperature and acidification. Finally, calcium bond formation showed a 
statistically significant effect of all studied factors and their interactions, although $80 \%$ of the model's sum of squares was taken by the acidification factor, indicating the great relevance of $\mathrm{pH}$ on calcium bond formation.

\section{Inter-Protein Chemical Bonds in Uninoculated Curd at $30^{\circ} \mathrm{C}$}

The relative proportion of hydrophobic, electrostatic+hydrogen, and calcium bonds in uninoculated curd during the $60 \mathrm{~min}$ of curing at $30^{\circ} \mathrm{C}$ is shown in Figure 3. From a theoretical point of view, this treatment is the mildest studied condition. The absence of $\mathrm{pH}$ development ensures constant solubility, concentration, ionization, and general chemical reactivity characteristics, for all present chemical species throughout the studied period. The low temperature used in this treatment limits the rate of chemical reactions compared with the higher temperature used in other treatments.

Under these conditions, Figure 3 shows how some regions of paracasein micelles, structurally stabilized through hydrophobic interactions in their original configuration, are disassembled throughout the curing time, reducing the proportion of hydrophobic interactions from $58 \%$ to $33 \%$.

Simultaneously, some new electrostatic+hydrogen and calcium bonds start to emerge in the newly formed proteinaceous structure, increasing from 21 to $38 \%$ and from 20 to $29 \%$, respectively. Previous reports have established that casein micelle destabilization caused by external factors gives rise to the formation of new links (Choi et al., 2007; Dalgleish, 2014). Casein amino acid residues such as Asp, Glu, and the $\mathrm{HPO}_{4}$ ion of the phosphoserine complex, are capable of establish- ing both electrostatic and calcium bonds, whereas Lys forms only electrostatic bonds (Gaucheron, 2011; Koutina et al., 2015; Mehta, 2018). Amino acid residues of Asn, Thr, Ser, Gln, Met, Tyr, and Trp are capable of establishing hydrogen bridges, whereas His and Arg are capable of forming both electrostatic and hydrogen interactions (Keim, 2005).

Electrostatic and hydrogen bonds developed more quickly than calcium bonds under the studied conditions, probably because soluble ionic calcium is not readily available at this $\mathrm{pH}$ level $(\mathrm{pH}$ 6.7). The moderate development of new electrostatic+hydrogen and calcium inter-protein bonds resulted in a moderate increase in protein-protein interactions, translating into a limited whey loss (4.8\% loss), as shown in Figure 2, for this treatment.

The hydrophobically stabilized region in the original micelle structure was only possible thanks to the colloidal stability conferred upon micelles by the glycomacropeptide in k-caseins (Fox and Guinee, 2013). Once absent, the old structure must turn into a new more thermodynamically stable one, which, to be formed, requires the dissolution of old bonds and the establishment of new ones (Huppertz, 2013). This bond reorganization process takes place following a hierarchical order, $\mathrm{CaB}>\mathrm{EB}>\mathrm{HB}>\mathrm{Hy}$, in which stronger bonds tend to replace weaker bonds as the disaggregation of the structure exposes new reactive sites (Table 2).

Some punctual values similar to those obtained in the present study have been reported in the literature (Table 3). Lefebvre-Cases et al. (1998) reported HB values of $30 \%$ in rennet skim milk gels of constant $\mathrm{pH}$ at $30^{\circ} \mathrm{C}$. Keim et al. (2006) reported values of $23 \%$ for $\mathrm{EB}+\mathrm{HB}$ in rennet gels under similar conditions. Benyahia-Krid et al. (2016) reported values of 42 to $46 \%$ for

Table 2. Properties of various interactions stabilizing inter-casein structures

\begin{tabular}{|c|c|c|c|}
\hline Type of interaction & Energy $(\mathrm{kJ} / \mathrm{mol})$ & Functional groups involved & Reference \\
\hline Calcium bridges $(\mathrm{CaB})$ & $90-97$ & $\begin{array}{l}\mathrm{H} \text { donor } \\
\text { Tyr, Thr, Ser residues } \\
\text { Residue } \mathrm{HPO}_{4}^{-} \\
\text {Asp and } \mathrm{Glu}^{-} \\
\text {Deprotonated } \mathrm{COO}^{-}\end{array}$ & $\begin{array}{l}\text { Keim (2005) } \\
\text { Gaucheron (2011) } \\
\text { Permyakov and Kretsinger (2011) }\end{array}$ \\
\hline Electrostatic interactions (EB) & $42-84$ & $\begin{array}{l}\text { Carboxyl } \mathrm{COO}^{-} \\
\text {(Asp, Glu) } \\
\text { Amino } \mathrm{NH}_{4}^{+} \\
\text {(His, Arg, Lys) }\end{array}$ & $\begin{array}{l}\text { Messens et al. (1997) } \\
\text { Keim (2005) }\end{array}$ \\
\hline Hydrogen bridges (HB) & $8-40$ & $\begin{array}{l}\mathrm{H} \text { atom of } \mathrm{OH}, \\
\mathrm{NH} \text { (donor), or } \\
\mathrm{CO} \text { (acceptor) groups }\end{array}$ & $\begin{array}{l}\text { Messens et al. (1997) } \\
\text { Keim (2005) }\end{array}$ \\
\hline
\end{tabular}




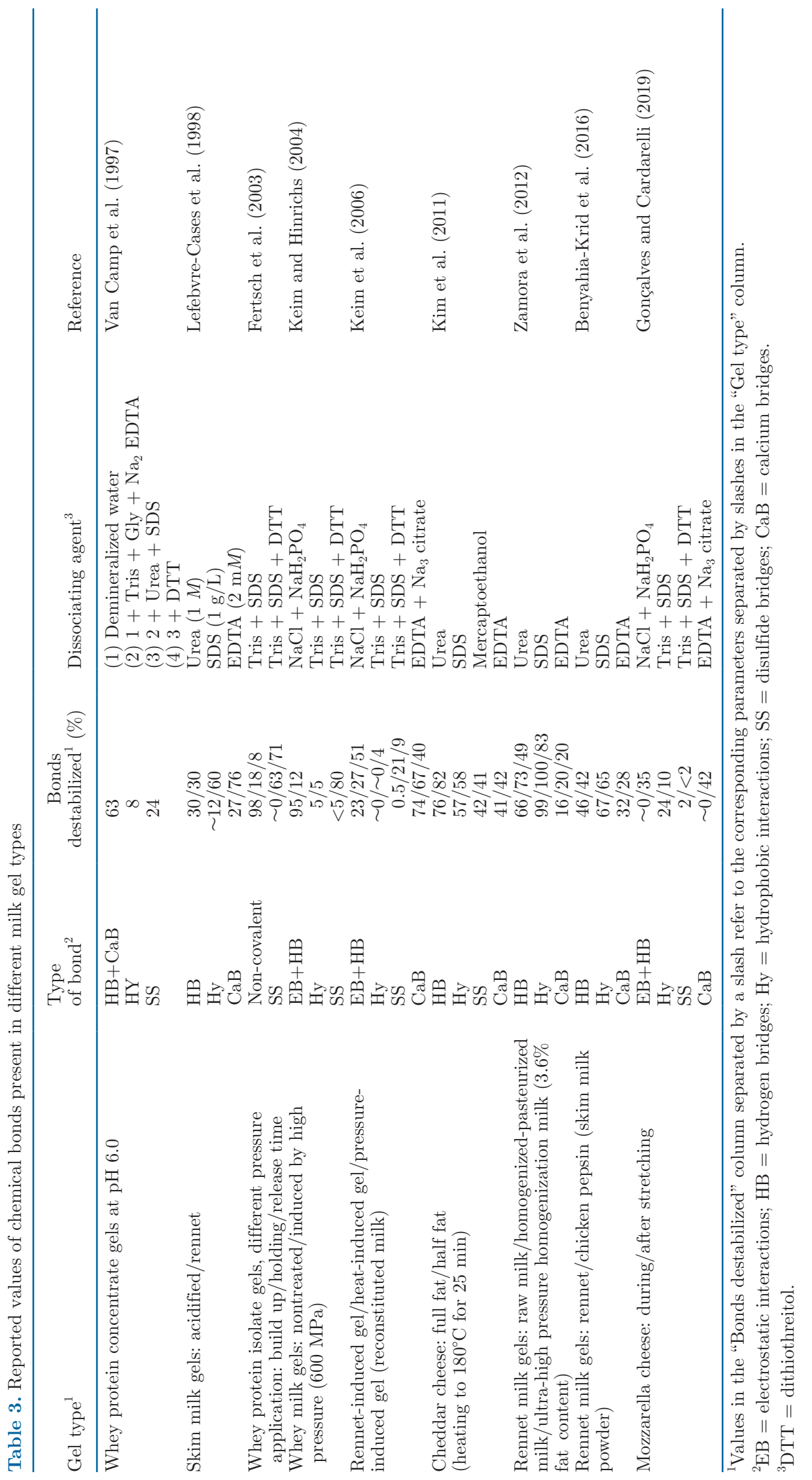




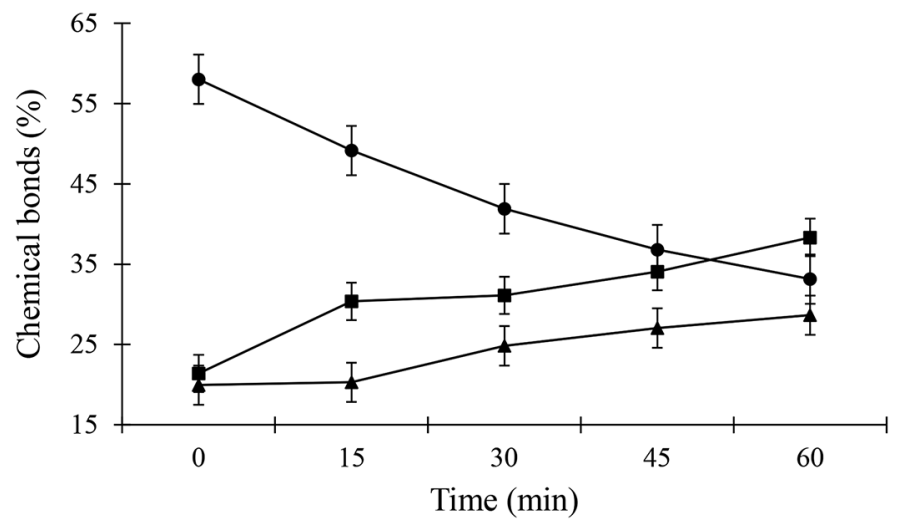

Figure 3. Inter-protein chemical bonds in uninoculated curd samples at $30^{\circ} \mathrm{C}$ are represented by different markers: hydrophobic interactions $(\boldsymbol{\bullet})$, electrostatic bonds and hydrogen bridges $(\boldsymbol{\square})$, and calcium bonds $(\boldsymbol{\Lambda})$. Error bars represent SE.

$\mathrm{HB}$, and 28 to $32 \%$ for $\mathrm{CaB}$ in skim milk powder gels prepared with different types of coagulant agents. Finally, Zamora et al. (2012) reported $\mathrm{CaB}$ values around $20 \%$ in curd made of milk subjected to high pressure.

\section{Inter-Protein Chemical Bonds in Uninoculated Curd at $40^{\circ} \mathrm{C}$}

Figure 4 shows the relative proportion of hydrophobic, electrostatic+hydrogen, and calcium bonds found in uninoculated curd cured at $40^{\circ} \mathrm{C}$ for $60 \mathrm{~min}$. This treatment, similar to the one previously described, did not induce curd $\mathrm{pH}$ changes during the studied period, ensuring constant chemical reactivity properties of all the present chemical species. The higher temperature employed in this treatment, however, increased the kinetic energy of the system, roughly doubling the reaction rate of all chemical changes, as established by the Arrhenius law. In agreement with this, the relative proportion of all studied chemical bonds at $40^{\circ} \mathrm{C}$ after 30 min coincided almost exactly with the values found at $30^{\circ} \mathrm{C}$ after $60 \mathrm{~min}$, showing an average difference of only $0.64 \%$.

Curd tempering at $40^{\circ} \mathrm{C}$ induced faster changes from the beginning of the curing process. By the first measurement (time 0 ), a large percentage of the hydrophobic interactions had already been severed, quickly reaching an asymptotic value around $34 \%$, which is nearly the same level of hydrophobic bond content found after 60 min at $30^{\circ} \mathrm{C}$ (Figure 3). The reduction of hydrophobic bonds was obviously caused by formation of new electrostatic+hydrogen bonds, which accounted for a much larger proportion $(44 \%)$ at time 0 in curd at $40^{\circ} \mathrm{C}$. Calcium bridges, on the other hand, again showed a low initial proportion $(22 \%)$, similar to what was observed at $30^{\circ} \mathrm{C}$, confirming the unavailability of soluble ionic calcium at high pH (Lamichhane et al., 2018; Horne, 2020). Calcium bridges increased up to $33 \%$ after 60 min at the expense of electrostatic+hydrogen bonds, which gradually yielded reaction sites to calcium. Whey loss increased under these conditions, roughly doubling whey loss at $30^{\circ} \mathrm{C}$ after $60 \mathrm{~min}$.

\section{Inter-Protein Chemical Bonds in Inoculated Curd at $30^{\circ} \mathrm{C}$}

The relative proportions of chemical bonds in LABinoculated curd samples cured at $30^{\circ} \mathrm{C}$ are shown in Figure 5. The low temperature employed in this treatment induced low chemical reaction rates, similar to what was observed in uninoculated curds at $30^{\circ} \mathrm{C}$. Nevertheless, the $\mathrm{pH}$ decrease resulting from moderate LAB metabolic activity in this treatment modified the reactivity of some chemical species and increased the availability of soluble ionic calcium, as previously reported (Bijl et al., 2013; McMahon and Oommen, 2013). Soluble ionic calcium may interact with nonprotonated Glu and Asp, whose abundance depends on $\mathrm{pH}$, becoming scarcer as $\mathrm{pH}$ lowers. Proteins are also capable of reacting with calcium through the amino acids Ser, Thr, and Tyr via intermediation of a phosphate group forming calcium-reactive phosphoserine, phosphothreonine, and phosphotyrosine (Keim, 2005; Horne, 2016). The relative abundance of these amino acids in individual caseins determines their potential for interaction through calcium bridges or other electrostatic interactions (Cooke and McSweeney, 2017; Sinaga et al., 2017; Kern et al., 2018).

The effect of the increase in soluble ionic calcium is immediately apparent, as the relative proportion of calcium bridges between proteins in this treatment is notably larger than in the rest of the studied treat-

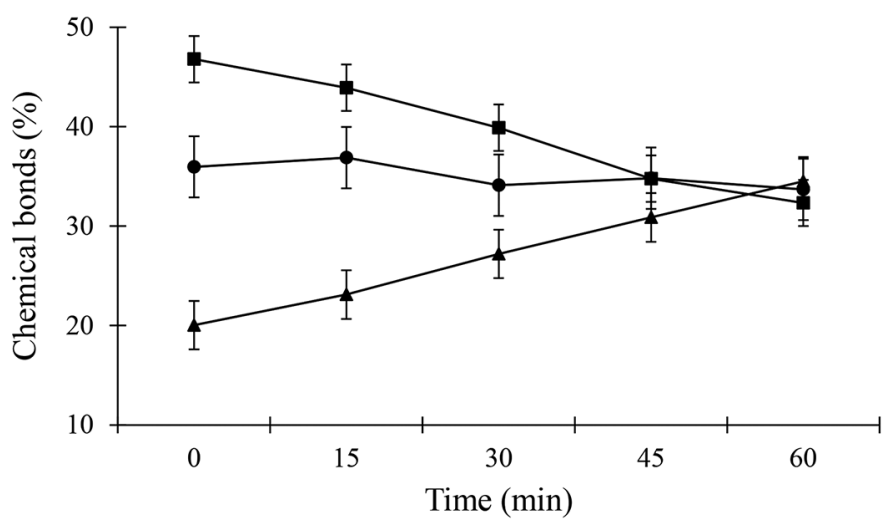

Figure 4. Inter-protein chemical bonds in uninoculated curd samples at $40^{\circ} \mathrm{C}$ are represented by different markers: hydrophobic interactions ( ), electrostatic bonds and hydrogen bridges ( $\mathbf{\square})$, and calcium bonds $(\mathbf{\Lambda})$. Error bars represent SE. 
ments $(68 \%)$. The observed values are similar to those reported by Keim et al. (2006) under similar conditions. The gradual decrease in hydrophobic bonds observed in uninoculated curds at $30^{\circ} \mathrm{C}$ in this case occurs abruptly even before the first measurement is conducted (time 0 ), probably forced by the sturdy structure developed by strong calcium bridges, reducing it below the levels previously observed (10\%). Although similar to what was observed in uninoculated curds at $40^{\circ} \mathrm{C}$, in this case hydrophobic interactions are mainly extinguished by calcium bridges and, to a lesser extent, by generic electrostatic+hydrogen bonds. Curd structure remains mainly calcium bridge-stabilized until the end of the 60-min curing period, although a slight recovery of hydrophobic interactions occurs at the expense of electrostatic+hydrogen bonds (32\% reduction) and, to a lesser extent, of calcium bridges (13\% reduction). This increase of hydrophobic bonds during the curing period may be related to the decrease of electrostatic repulsion experienced among caseins as $\mathrm{pH}$ lowers, reducing their net charge (Gonçalves and Cardarelli, 2019). Curd whey content remained relatively high throughout the curing period, similar to what was observed in uninoculated curd cured at $40^{\circ} \mathrm{C}$. The limited $\mathrm{pH}$ reduction marginally modified the water-holding capacity of curds (Lin et al., 2018; Mehta, 2018).

\section{Inter-Protein Chemical Bonds in Inoculated Curd at $40^{\circ} \mathrm{C}$}

Finally, assessment of the relative proportions of chemical bonds found in LAB-inoculated curd cooked at $40^{\circ} \mathrm{C}$ for $60 \mathrm{~min}$ is shown in Figure 6 . In this treatment, hydrophobic bonds maintained relative abundance levels around $22 \%$ throughout the studied 60-min period. This value is roughly double what was observed at the beginning of the curing period at $30^{\circ} \mathrm{C}$, as higher temperatures increase the dominance of hydrophobic interactions, reducing the contribution of electrostatic interactions (Giroux et al., 2014; Lamichhane et al., 2018). Generic electrostatic+hydrogen bonds developed more quickly at $40^{\circ} \mathrm{C}$ than at $30^{\circ} \mathrm{C}$, as predicted by the Arrhenius law, limiting the proportion of calcium bonds formed in the initial stages of the curing period. Nevertheless, calcium bonds quickly recovered their preponderance. As the curing period proceeded, calcium bonds gradually substituted electrostatic bonds, accumulating over time. The sum of calcium and electrostatic+hydrogen bonds remained practically constant throughout curing time. The relative proportion of calcium bonds found in inoculated curd cured at $40^{\circ} \mathrm{C}$ for $60 \mathrm{~min}$ seems to coincide with the value which calcium bonds in inoculated curd cured at $30^{\circ} \mathrm{C}$ approached after $60 \mathrm{~min}(52 \%)$.

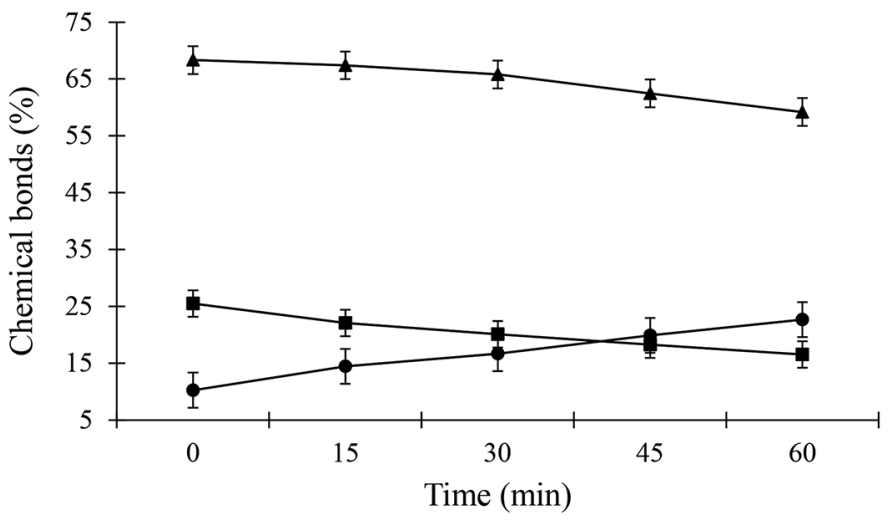

Figure 5. Inter-protein chemical bonds in inoculated curd samples at $30^{\circ} \mathrm{C}$ are represented by different markers: hydrophobic interactions $(\mathbf{\bullet})$, electrostatic bonds and hydrogen bridges (ם), and calcium bonds (ム). Error bars represent SE.

The water-binding capacity of curd was drastically reduced at $40^{\circ} \mathrm{C}$, as $\mathrm{pH}$ in this treatment is much lower than at $30^{\circ} \mathrm{C}$ (Giroux et al., 2014; Lamichhane et al., 2018). Therefore, although the proportion of hydrophobic bonds to combined calcium, electrostatic, and hydrogen bonds at $60 \mathrm{~min}$ is roughly $20: 80$ in both 30 and $40^{\circ} \mathrm{C}$ treatments, their whey content differs greatly (Figure 2).

\section{CONCLUSIONS}

Although visually all studied conditions coagulated milk in a similar manner, different temperature and acidity conditions strongly affected the relative proportions of inter-protein chemical bonds found in curd. Disulfide bridges were not affected by the experimental conditions, remaining at a constant level of $1.58 \%$ in all treatments. Electrostatic interactions (including

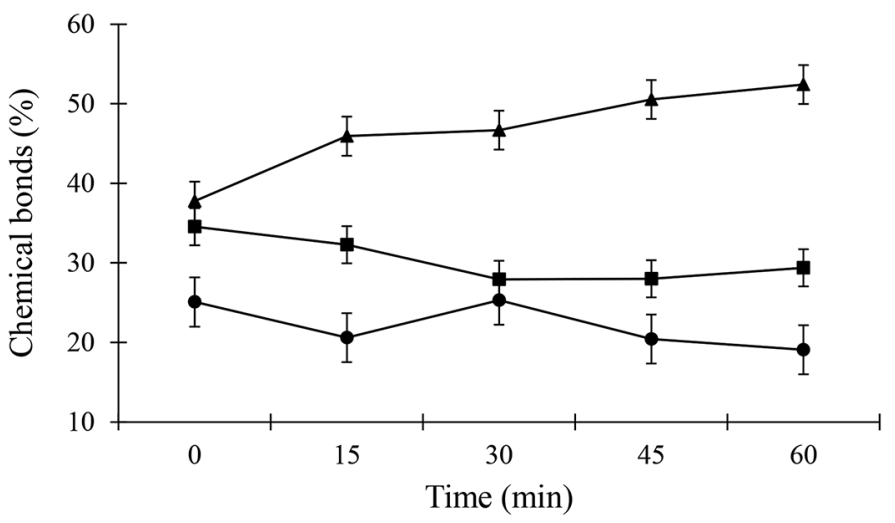

Figure 6. Inter-protein chemical bonds in inoculated curd samples at $40^{\circ} \mathrm{C}$ are represented by different markers: hydrophobic interactions $(\boldsymbol{\bullet})$, electrostatic bonds and hydrogen bridges ( $\mathbf{\square})$, and calcium bonds (४). Error bars represent SE. 
calcium and hydrogen bridges) quickly substituted the hydrophobic interactions that stabilized the original structure of casein micelles in milk before the action of chymosin. Treatment temperature affected reaction rate, as established by the Arrhenius law. pH-dependent soluble ionic calcium availability defined the balance between electrostatic+hydrogen bonds and calcium bridges. In general, stronger bonds tended to replace weaker bonds as the disaggregation of the structure exposed new reactive sites, following the hierarchical order $\mathrm{CaB}>\mathrm{EB}>\mathrm{HB}>\mathrm{Hy}$. The different combinations of $\mathrm{pH}$ and temperature during curd curing promoted the establishment of different proteinaceous structures. Although $\mathrm{pH}$ defined the nature of the interactions among proteins in curd, temperature modified the rate at which such bonds were formed. Determining how the differently stabilized curd structures translate into the microstructure and physical properties of finished cheese and other intermediate products remains a relevant topic.

\section{ACKNOWLEDGMENTS}

The authors thank Veronica Gonzalez and Angel Esparza (Centro de Investigación en Alimentacion y Desarrollo A.C., Unidad Cuauhtémoc, Ciudad Cuauhtémoc, Chihuahua, Mexico) for their technical assistance. Author Amaro-Hernández thanks the Mexican National Council of Science and Technology (CONACYT; Mexico City) for providing financial support for his graduate studies. The authors have not stated any conflicts of interest.

\section{REFERENCES}

Amaro-Hernández, J. C., G. I. Olivas, C. H. Acosta-Muñiz, N. Gutiérrez-Méndez, and D. R. Sepulveda. 2020. Structure rearrangement during rennet coagulation of milk modifies curd density. J. Dairy Sci. 103:3088-3094. https://doi.org/10.3168/jds.2019-16998.

AOAC International. 2006a. Moisture in cheese, method no. 926.08. Official Methods of Analysis, 18th ed. AOAC International.

AOAC International. 2006b. Solids (total) in milk, method no. 990.20. Official Methods of Analysis, 18th ed. AOAC International.

AOAC International. 2006c. Kjeldahl method, method no. 2001.14 Official Methods of Analysis, 18th ed. AOAC International.

Benyahia-Krid, F., O. Aissaoui-Zitoun, H. Boughellout, F. Adoui, and A. Harkati. 2016. Chicken pepsin and rennet gels: Internal bonds, rheology and microstructure. J. Vet. Sci. Technol. 7:375. https:// doi.org/10.4172/2157-7579.1000375.

Bijl, E., H. Van Valenberg, T. Huppertz, and A. Van Hooijdonk. 2013. Protein, casein, and micellar salts in milk: Current content and historical perspectives. J. Dairy Sci. 96:5455-5464. https://doi .org/10.3168/jds.2012-6497.

Broyard, C., and F. Gaucheron. 2015. Modifications of structures and functions of caseins: A scientific and technological challenge. Dairy Sci. Technol. 95:831-862. https://doi.org/10.1007/s13594-015 -0220-y.

Choi, J., D. Horne, and J. Lucey. 2007. Effect of insoluble calcium concentration on rennet coagulation properties of milk. J. Dairy Sci. 90:2612-2623. https://doi.org/10.3168/jds.2006-814.
Cooke, D. R., and P. L. McSweeney. 2017. From micelle to melt: The influence of calcium on physico-chemical properties of cheese. Pages 20-44 in Global Cheesemaking Technology: Cheese Quality and Characteristics. 1st ed. P. Papademas and T. Bintsis, ed. John Wiley \& Sons.

Corredig, M., and E. Salvatore. 2016. Enzymatic coagulation of milk. Pages 287-307 in Advanced Dairy Chemistry. P. L. H. McSweeney and P. F. Fox, ed. Springer.

Dalgleish, D. G. 2014. The basis of structure in dairy-based foods: Casein micelles and their properties. Pages 83-105 in Food Structures, Digestion and Health. 1st ed. M. Boland, M. Golding, and H. Singh, ed. Elsevier.

Fagan, C. C., D. J. O'Callaghan, M. J. Mateo, and P. Dejmek. 2017. The syneresis of rennet-coagulated curd. Pages 145-177 in Cheese: Chemistry, Physics and Microbiology. 4th ed. P. F. Fox, P. L. H. McSweeney, T. M. Cogan, and T. P. Guinee, ed. Elsevier.

Fertsch, B., M. Müller, and J. Hinrichs. 2003. Firmness of pressureinduced casein and whey protein gels modulated by holding time and rate of pressure release. Innov. Food Sci. Emerg. Technol. 4:143-150. https://doi.org/10.1016/S1466-8564(03)00008-0.

Fox, P. F., and T. P. Guinee. 2013. Cheese science and technology. Pages 357-389 in Milk and Dairy Products in Human Nutrition: Production, Composition and Health, 1st ed. Y. W. Park and G. F. W. Haenlein, ed. Wiley Blackwell.

Fox, P. F., T. P. Guinee, T. M. Cogan, and P. L. McSweeney. 2017. Chemistry of milk constituents. Pages 71-104 in Fundamentals of Cheese Science. P. F. Fox, T. P. Guinee, T. M. Cogan, and P. L. H. McSweeney, ed. Springer.

Gaucheron, F. 2011. Milk salts: Distribution and analysis. Pages 908916 in Encyclopedia of Dairy Sciences. 2nd ed. P. McSweeney, J. Fuquay, and P. Fox, ed. Elsevier.

Geng, X. L., F. W. van den Berg, A. N. Bager, and R. Ipsen. 2011. Dynamic visualization and microstructure of syneresis of cheese curd during mechanical treatment. Int. Dairy J. 21:711-717. https: //doi.org/10.1016/j.idairyj.2011.01.013.

Giroux, H. J., C. Bouchard, and M. Britten. 2014. Combined effect of renneting $\mathrm{pH}$, cooking temperature, and dry salting on the contraction kinetics of rennet-induced milk gels. Int. Dairy J. 35:7074. https://doi.org/10.1016/j.idairyj.2013.10.016.

Gonçalves, M. C., and H. R. Cardarelli. 2019. Composition, microstructure and chemical interactions during the production stages of Mozzarella cheese. Int. Dairy J. 88:34-41. https://doi.org/10 .1016/j.idairyj.2018.07.005.

Horne, D. 2016. Casein: Micellar structure (Dual-binding model). Pages 1-8 in Reference Module in Food Science. Elsevier.

Horne, D. S. 2020. Casein micelle structure and stability. Pages 213250 in Milk Proteins. 3rd ed. M. Boland and H. Singh, ed. Elsevier.

Huppertz, T. 2013. Chemistry of the caseins. Pages 135-160 in Advanced Dairy Chemistry. P. L. H. McSweeney and P. F. Fox, ed. Springer.

Janhøj, T., and K. Qvist. 2010. The formation of cheese curd. Pages 130-165 in Technology of Cheesemaking. 2nd ed. B. A. Law and A. Y Tamime, ed. Wiley-Blackwell.

Keim, S. 2005. Hydrostatic, Thermal, Acid and Rennet Induced Casein and Whey Protein Gels: Stabilizing Bonds and Textural Properties. Shaker.

Keim, S., and J. Hinrichs. 2004. Influence of stabilizing bonds on the texture properties of high-pressure-induced whey protein gels. Int. Dairy J. 14:355-363. https://doi.org/10.1016/j.idairyj.2003.10 .010 .

Keim, S., U. Kulozik, and J. Hinrichs. 2006. Texture and stabilizing bonds in pressure-induced, heat-induced and rennet-induced milk protein gels. Milchwissenschaft 61:363-366.

Kern, C., J. Weiss, and J. Hinrichs. 2018. Additive layer manufacturing of semi-hard model cheese: Effect of calcium levels on thermorheological properties and shear behavior. J. Food Eng. 235:89-97. https://doi.org/10.1016/j.jfoodeng.2018.04.029.

Kim, S. Y., S. Lim, and S. Gunasekaran. 2011. Protein interactions in reduced-fat and full-fat Cheddar cheeses during melting. Lebensm. Wiss. Technol. 44:582-587. https://doi.org/10.1016/j.lwt.2010.07 .011 . 
Koutina, G., J. C. Knudsen, U. Andersen, and L. H. Skibsted. 2015. Influence of colloidal calcium phosphate level on the microstructure and rheological properties of rennet-induced skim milk gels. Lebensm. Wiss. Technol. 63:654-659. https://doi.org/10.1016/j .lwt.2015.03.035.

Lamichhane, P., A. L. Kelly, and J. J. Sheehan. 2018. Symposium review: Structure-function relationships in cheese. J. Dairy Sci. 101:2692-2709. https://doi.org/10.3168/jds.2017-13386.

Lefebvre-Cases, E., E. Gastaldi, V. Vidal, S. Marchessau, A. Lagaude, J.-L. Cuq, and B. T. De La Fuente. 1998. Identification of interactions among casein gels using dissociating chemical agents. J. Dairy Sci. 81:932-938. https://doi.org/10.3168/jds.S0022 -0302(98)75653-X.

Lin, L., M. Wong, H. Deeth, and H. Oh. 2018. Calcium-induced skim milk gels using different calcium salts. Food Chem. 245:97-103. https://doi.org/10.1016/j.foodchem.2017.10.081.

Lucey, J. A. 2014. Milk protein gels. Pages 493-523 in Milk Proteins: From Expression to Food. A. Thompson, M. Boland, and H. Singh, ed. Elsevier.

McMahon, D. J., and B. S. Oommen. 2013. Casein micelle structure, functions, and interactions. Pages 185-209 in Advanced Dairy Chemistry. P. L. H. McSweeney and P. F. Fox, ed. Springer.

Mehta, B. M. 2018. Microstructure of cheese products. Pages 145-179 in Microstructure of Dairy Products, 1st ed. M. El-Bakry, A. Sanchez, and B. M. Mehta. John Wiley \& Sons.

Messens, W., J. Van Camp, and A. Huyghebaert. 1997. The use of high pressure to modify the functionality of food proteins. Trends Food Sci. Technol. 8:107-112. https://doi.org/10.1016/S0924 -2244(97)01015-7.

Ono, W., D. Oka, A. Hamakawa, T. Noguchi, and K. Takano. 2017. Effects of $\kappa$-casein dissociation from casein micelles on cheese curd formation. Food Sci. Technol. Res. 23:743-748. https://doi.org/10 $.3136 /$ fstr.23.743
Panteli, M., E. Zoidou, and G. Moatsou. 2015. Comparative study of the paracasein fraction of two ewe's milk cheese varieties. J. Dairy Res. 82:491-498. https://doi.org/10.1017/S0022029915000254.

Permyakov, E., and R. H. Kretsinger. 2011. Stoichiometry, kinetics, and thermodynamics of calcium binding. Pages 71-82 in Calcium Binding Proteins. E. A. Permyakov and R. H. Kretsinger. John Wiley \& Sons.

Sinaga, H., N. Bansal, and B. Bhandari. 2017. Effects of milk pH alteration on casein micelle size and gelation properties of milk. Int. J. Food Prop. 20:179-197. https://doi.org/10.1080/10942912 .2016.1152480.

Van Camp, J., W. Messens, J. Clément, and A. Huyghebaert. 1997. Influence of $\mathrm{pH}$ and sodium chloride on the high pressure-induced gel formation of a whey protein concentrate. Food Chem. 60:417-424. https://doi.org/10.1016/S0308-8146(96)00362-7.

van Vliet, T., C. M. Lakemond, and R. W. Visschers. 2004. Rheology and structure of milk protein gels. Curr. Opin. Colloid Interface Sci. 9:298-304. https://doi.org/10.1016/j.cocis.2004.09.002.

Walstra, P., J. T. Wouters, and T. J. Geurts. 2005. Cheese manufacture. Pages 583-639 in Dairy Science and Technology. P. Walstra, J. T. M. Wouters, T. J. Geurts, ed. CRC Press.

Zamora, A.. A. Trujillo, E. Armaforte, D. Waldron, and A. Kelly 2012. Effect of fat content and homogenization under conventional or ultra-high-pressure conditions on interactions between proteins in rennet curds. J. Dairy Sci. 95:4796-4803. https://doi.org/10 $.3168 /$ jds.2012-5351.

\section{ORCIDS}

G. I. Olivas @ https://orcid.org/0000-0001-8242-8614

N. Gutiérrez-Méndez (ㄴ) https://orcid.org/0000-0002-0791-3211

D. R. Sepulveda (ํ) https://orcid.org/0000-0002-0400-8873 